\title{
THE CLIMATE OF THE CONTINENT OF AFRICA
}

By ALEXANDER KNOX, B.A. (Cantab.), F.R.G.S.

Royal 8vo. With 13 maps and a diagram

Price 21s. net

\begin{abstract}
"Such a work as this has not only become highly necessary, but should be in great demand amongst Governments, mining and commercial companies trading in Africa, missionary societies, and all individuals who intend to visit Africa for any length of time, or to settle in any part of that continent for purposes of health, science, education, or commercial gain.... The maps contributed to this book by Mr J. G. Bartholomew under the direction of the author are admirable, and great praise must be awarded to the author for his general research, the clearness with which he sets forth his details and his conclusions, and the way in which he has invested what might seem to be a somewhat uninteresting subject with an interest and an importance sufficient to attract the general reader as well as the specialist. The book...should prove a standard work." - Sir H. H. JonnstoN in Nature
\end{abstract}

"Mr Knox has done great service in compiling from a great number of sources the data for his book on the climate of Africa.... The book is written concisely, but with admirable clearness, and adequate statistics are given. Thanks to the immense industry of $\mathrm{Mr}$ Knox those who are interested in the social or economio development of Africa or intending settlers or travellers are now in a position to understand the climatic conditions of any part of the continent.... A word of praise is due for the beautifully-executed maps which illustrate the mean annual rainfall and the mean rainfall for each month."-Dr A. C. HAdDon in the Morning Post

CAMBRIDGE UNIVERSITY PRESS, FETTER LANE, LONDON

C. F. CLAY, Manager

\section{OXFORD UNIVERSITY PRESS}

\section{Quarterly Journal of Medicine}

Edited by

WILLIAM OSLER, J. ROSE BRADFORD, R. HUTCHISON, A. E. GARROD, H. D. ROLLESTON AND W. HALE WHITE.

8s. 6d. net per number. Annual Subscription, 25s. Vol. I, 1907-8 (I-IV). Vol. II, 1908-9 (V-VIII). Vol. III, 1909-10 (IX-XII). Vol. IV, 1910-11 (XIII-XVI),

35s. net each.

The King's Evil. By R. Crawfurd. Medium 8vo, with nine plates. $8 s .6 d$. net.

The Last Days of Charles II. By the same. With a drawing from the Effigy in Westminster Abbey reproduced in collotype, and four other illustrations. Medium 8vo. 58. net.

English Medicine in Anglo=Saxon Times: the Fitz-Patrick Lectures for 1903, By J. F. PAYNE. 8vo, with 23 illustrations. 8s, $6 d$. net.

The Study of Medicine in the British Isles: the Fitz-Patrick Lectures for 1905-6. By Norman Moore. 8vo, with 13 Collotype plates. 10s. $6 d$. net.

The Treatment of Disease. By W. OsLer. 1s. net.

A Handbook of Anatomy for Art Students : fully illustrated. By Arthur Thomson. Third edition, 1906. 8vo, buckram. 16s. net. 


\section{PAUL ALTMANN,}

47, Luisen-Strasse,

Ecke Schumann-Strasse, BERLIN, N.W., GERMANY,

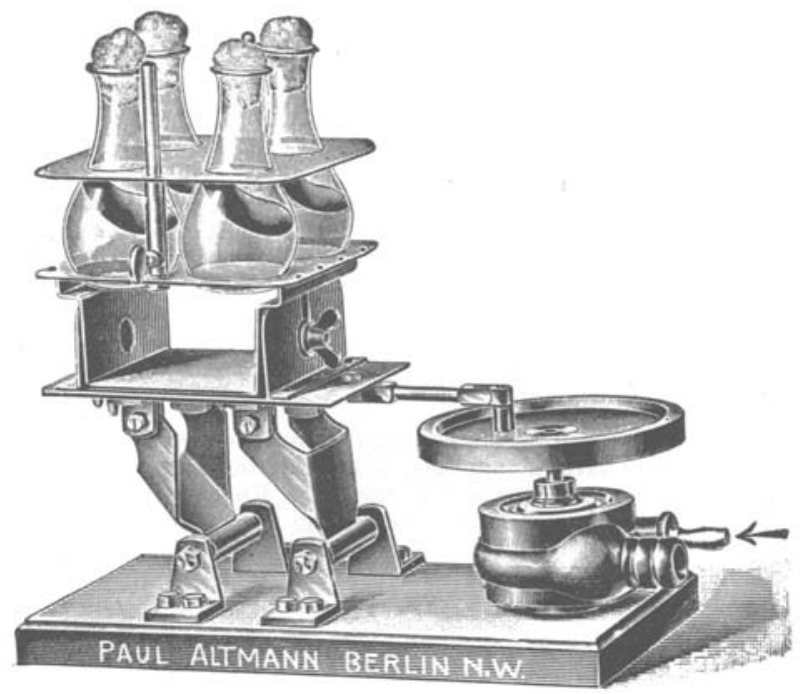

New SHAKING APPARATUS with Water Motor. Mk. 45.00.
Manufacturer of all kinds of apparatus and appliances for Chemistry, Bacteriology, Microscopy and Hygiene.

All Goods manufactured in our own workshops.

COMPLETE OUTFITS of Bacteriological-Microscopical and Hygieno-Chemical Laboratories.

SPECIALITY :

Disinfecting and Sterilising Apparatus.

Thermostats, adjustable for a Constant Temperature. Autoclaves, Centrifugals. Apparatus for Clinical Laboratories, etc., etc.

New apparatus for WATER RESEARCHES.

New apparatus for SERODIAGNOSE. Full Illustrated Price Lists on Application.

\title{
GRIFFIN'S
}

KEMBLE STREET

KINGSWAY, LONDON, W.C.

General Laboratory Apparatus

Bacteriological Equipment

Microscopes

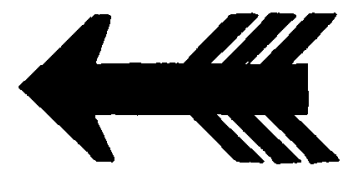

Clinical Apparatus

Centrifugals (Mand and

Kahlbaum's Pure Chemicals

\section{TICKS A Monograph of the Ixodoidea}

By GEORGE H. F. NUTTALL, M.D., Ph.D., Sc.D., F.R.S., CECIL WARBURTON, M.A., F.Z.S., W. F. COOPER, B.A., F.Z.S., F.L.S. and L. E. ROBINSON, A.R.C.Sc. (London)

\author{
Now ready $\left\{\begin{array}{l}\text { PART I. THE ARGASIDAE. } 5 s . \text { net } \\ \text { PART II. THE IXODIDAE. 12s. net } \\ \text { BIBLIOGRAPHY OF }\end{array}\right.$
}




\section{THE \\ CAMBRIDGE UNIVERSITY PRESS BULLETIN}

\section{No. XXVI April XXIX, MCMXII}

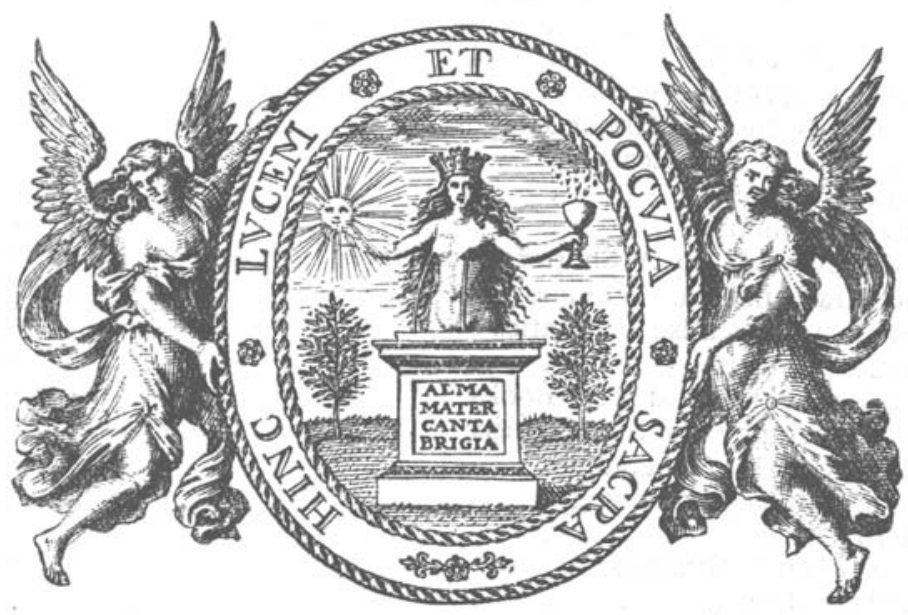

Notes on books published at the Cambridge University Press Fetter Lane, London, E.C.

C. F. Clay, Manager 


\section{CONTENTS}

Christian Epigraplyy.

Caesar in Britain and Belgium

An English-Greek Lexicon

Thucydides : Book IV

A First Year Latin Book

A Short Syntax of New Testament Greek

Cambridge English Classics: Sidney's Arcadia

Widsith

Cambridge History of English Literature. Volume VIII

A First German Book

Nineteenth Century Essays

Catalogue of the Acropolis Museum Volume I

Themis

Prehistoric Thessaly .

The Early English Dissenters

Foreign Companies and other Corporations . . . . . . . $\quad$ I7

A History of the American Bar

Differential Geometry

A Shorter Geometry

Notes and-Answers to A Shorter Geometry

Principia Mathematica. Volume II

An Elementary Treatise on Statics

Cambridge Manuals

Cambridge Geographical Text-Books

Physical Geography for South Africa

Cambridge County Geographies

Byways in British Archaeology

The Heroic Age

English Provincial Printers

The Scottish Liturgy

Permissible Additions to and Deviations from the Service Books of the Scottish Church as Canonically Sanctioned

Horae Semiticae, No. IX.

The Revised English Grammar

The Revised Engtish Grammar for Beginners. ${ }^{\cdot} \cdot \cdot^{\cdot} \cdot{ }^{\cdot} 30$

Nathan der Weise. . . . . . . . . 30

The Study of 'Timber and Forest Products in America . . . 30

Catalogue of MSS. in the Library of Corpus Christi College. Pt. VI $3^{\mathbf{I}}$

Biographical History of Gonville and Caius College. Vol. IV . 3 I

The Works of John Caius, M.D. . . . . . . . 3

Biometrika. Vol. VIII, Parts 3 and $4 . \quad$. . . . . 3 I

The British Journal of Psychology. Vol. IV, Parts 3 and $4 . \quad 3$ I

The Journal of Agricultural Science. Vol. IV, Part $3 .{ }^{2} .3^{r}$

The Journal of Genetics. Vol. I, No. 4 and Vol. II, No. I . 3I

The Journal of Hygiene. Vol. XI, No. 4 and Plague Supplement I 3 I

The Journal of Physiology. Vol.XLIII, No.6; Vol. XLIV, Nos. I and 23 I

The Modern Language Review. Vol. VII, Nos. I and 2 . . 32

Parasitology. Vol. IV, No. 4; Vol. V, No. I . . . . $3^{2}$

English Composition . . . . . . . . . . . 32

German Grammar . . . . . . . . . . . $3^{2}$ 
Primitive Christian Eschatology. Being the Hulsean Prize Essay for 1908. By E. C. Dewick, M.A., Tutor and Dean of St Aidan's College, Birkenhead and Teacher in Ecclesiastical History in the University of Liverpool.

Demy 8vo. pp. $\mathrm{xx}+4 \mathrm{I} 6$. Price IOs. $6 d$. net.

\section{Extract from the Introduction}

Eschatology, dealing as it does with the unknown future, possesses at all times a peculiar fascination for the human mind....It is indeed true that during the latter part of the nineteenth century, the Doctrine of the Last Things seemed to be receding into the background of Christian teaching... but in the last few years this very doctrine has been thrust forward into great prominence by the efforts of a certain school of thought in Germany, who maintain that the very core and essence of Christianity, as taught by Jesus Christ, lay in his eschatological teaching....and the whole question of the Christian Doctrine of the Last Things stands in the forefront of modern theological problems.

The method which has been pursued in this essay is as follows :-

In Part I the main features of Old Testament Eschatology are discussed.

In Part II we have dealt with the writings of later Judaism and especially the apocalyptic literature.

Part III deals with the most important section of our subject-the eschatology of our Lord.

In Part IV we have considered the eschatology of the apostles.

Part $V$ treats of Christian Eschatology in the first and second centuries.

In Part VI we have endeavoured to indicate the evidential value of Primitive Christian Eschatology, and to point out some of the ways in which it confirms the claims of Christ's Religion. 
Christian Epigraphy. An Elementary Treatise, with a collection of ancient Christian inscriptions mainly of Roman origin. By Orazio Marucchi, Professor of Christian Archaeology in the Royal University of Rome. Translated by J. Armine Willis.

Pott 8vo. pp. xii +460 . With 30 plates. Price $7 s .6 d$. net.

\section{Extract from the Prefatory Note by $D r M$. R. James}

Dr Marucchi's work is primarily concerned with the inscriptions of Rome, though important monuments from elsewhere find a place in it.... The author's plan has been to select from the bewildering mass of extant material sufficient specimens of all the main classes of Christian inscriptions to familiarise the reader with the current formulae...to interpret methods of dating and to appreciate the bearing of the monuments upon history. Under such guidance it becomes possible to realise the importance, the interest, and the beauty of these early documents.

Caesar in Britain and Belgium. Simplified Text with Introduction, Notes, Exercises and Vocabulary by J. H. Sleeman, M.A., Late Fellow of Sidney Sussex College, Cambridge and Lecturer in Latin in the University of Sheffield.

Pitt Press Series. Extra fcap. 8vo. pp. xxx +123.

With 12 illustrations and a map. Price $1 s .6 d$.

\section{Extract from the Preface}

The text of this little book, which is based on Caesar, $B$. G. IV. $20-38$, and v. I -23 and $38-52$, presents an attempt to follow out the recommendations of a Committee of the Classical Association and to provide a continuous Latin narrative, not too difficult for pupils who have learnt Latin for only a year. Long sentences have been broken up or curtailed... and much of the early part of the selection has been entirely rewritten.... What little oratio obliqua the text contains is of the simplest kind.... The notes are mainly grammatical... The exercises are based on the text but, it is hoped, do not follow it too slavishly. It is thought that some at least may be done viva voce in class.... In the introduction I have given some account of Caesar's life and of Roman military institutions. 
An English-Greek Lexicon, with an introduction and appendices. By G. M. Edwards, M.A., Fellow of Sidney Sussex College, Cambridge.

Fcap. 4to. pp. xxxii +332 . Price 7s. $6 d$. net.

\section{Extract from the Preface}

In this book my chief endeavour has been to interest the student in the wonderful riches of the Greek language, its idioms and its vocabulary. I do not advocate the constant use of the "English-Greek" in composition at school or at the University...but I have found, in the course of a long experience, that the entire absence of this aid often produces a meagreness of language which is most discouraging to the writer. It is a characteristic of the young student who has any feeling for style to revel in fine words.

\section{CONTENTS OF INTRODUCTION}

I. Prose and Verse Vocabulary

II. Note on the Greek of Herodotus

III. The dialect of Tragedy

IV. The importance of Aristophanes for Greek lexicography

V. Thucydides

VI. The Attic Orators

VII. Plato

VIII. Xenophon a bad authority for Attic

IX. The new Hellenica

$\mathrm{X}$. Notes on development in the Greek language

XI. Ornate equivalents

XII. The Athenian ideal illustrated by the vocabulary

XIII. Notes on Quantity

Athenaeum. The work of a sound scholar, and, as its 320 pages supply a good grounding in vocabulary, separating verse and prose, it is likely to be adopted for the use of young students.... The Introduction is more fitted for advanced Grecians than for beginners. It is, in fact, a sketch of great interest, depending on fine scholarship, and affording an admirable insight into the wonderful grace and variety of Greek.

Thucydides: Book IV. Edited, with an introduction and notes, by A. W. Spratt, M.A., Fellow and Tutor of St Catharine's College, Cambridge.

Pitt Press Series. Extra fcap. 8vo. pp. $x x+448$. Price $6 s$. 
A First Year Latin Book. By John Thompson, M.A., formerly Scholar of Christ's College, Cambridge, Head Master of the High School, Dublin.

\author{
Extra Fcap. 8vo. pp. xviii +227 . Price $2 s$.
}

\title{
Extract from the Introduction
}

This book is an attempt to meet the requirements of the first year of learning Latin, as prescribed by the Report of the Curricula Committee of the Classical Association.

The following points should (according to the Report) be borne in mind in a book containing work for the first year:

(I) Vocabulary: At least 500 of the commonest words should be mastered during the year.

(2) Repetition: Words and forms should be frequently repeated until the learner is thoroughly familiar with them.

(3) Methods of teaching: A variety of methods should be used such as $(a)$ Oral question and answer in Latin, (b) Repetition of sentences with changes of tense and other variations, $(c)$ Conversion of simple English sentences into Latin, (d) Comparison of Latin words with French and English derivatives.

In this book the different forms of the simple sentence are treated first side by side with the development of the regular accidence, and then some of the commonest and simplest forms of subordinate clauses with the indicative and subjunctive moods... The chief uses of the cases are also introduced, and the principal prepositions. The accidence covers the five regular declensions of nouns, the declensions of the adjectives and pronouns, the formation of adverbs, the numerals, the four conjugations of the regular verb in the active voice throughout, and in the present passive (excluding all the participles), and the conjugation of sum, the $-i \overline{\bar{o}}$ verbs like capio, and the chief irregular verbs.

A Short Syntax of New Testament Greek. By Rev. H. P. V. Nunn, M.A., St John's College, Cambridge, sometime Lecturer at St Aidan's College, Birkenhead.

Crown 8vo. pp. xii +140 . Priçe 2s. 6d. net. 


\section{Sir Philip Sidney. The Countesse of Pembrokes} Arcadia. Edited by Albert Feuillerat, Professor of English Literature in the University of Rennes.

Cambridge English Classics. Large Crown 8vo. Cloth. pp. xii +572 .

$$
\text { Price } 4 \text { s. 6d. net. }
$$

(Forming Volume I of the Complete Works of Sir Philip Sidney in Three Volumes)

\section{Extract from Prefatory Note}

Reprints of the separate works of Sir Philip Sidney are numerous; yet, however incredible this may seem, no complete edition has hitherto been accessible. The object of the volumes now offered to Elizabethan students is to collect all the literary productions of. Sidney: The Countesse of Pembrokes Arcadia, the Poems and The Defence of Poesic as well as the Correspondence and the Political Pamphlets. I even propose to include the translations of the Psalms and of Mornay's Verite de la Religion Chrestienne, it being possible to ascertain Sidney's share in these works....

In accordance with the scheme of The Cambridge English Classics, the text adopted is printed without any deviations from the original in the matter of spelling and punctuation, save those recorded in the list found on page 520 . These exceptions consist of evident misprints which it has been thought useless to preserve. In the Notes, I have given the variant readings supplied by all the editions (fourteen in number) published from 1593 down to 1674 .

\section{Widsith. A Study in Old English Heroic Legend.} By R. W. Chambers, M.A., Fellow and Librarian of University College, London.

Demy 8vo. pp. xii+263. With two maps. Price Ios. net.

\section{CONTENTS}

I. Widsith and the German Heroic Age

II. The stories known to Widsith: Gothic and Burgundian heroes

III. Tales of the sea-folk, of the Franks, and of the Lombards

IV. Widsith and the Critics

V. The Geography, of Widsith

VI. The Language and Metre of Widsith

VII. Summary and Conclusion

Text of Widsith, with Notes

Appendix

Maps and Index 


\section{The Cambridge History of English Literature. Volume VIII, The Age of Dryden. Edited by A. W. Ward, Litt.D., P.B.A., Master of Peterhouse, and A.R. Waller, M.A., Peterhouse.}

Royal 8vo. pp. xiv +516. Price, in buckram 9s. net, in half-morocco I $5 s$. net.

\section{CONTENTS}

CHAP.

I. Dryden. By A. W. WARD, Litt.D., P.B.A.

II. Samuel Butler. By W. F. Smith, M.A.

III. Political and Ecclesiastical Satire. By C. W. Previté-Orton, M.A.

IV. The Early Quakers. By Edward Grubb, M.A.

V. The Restoration Drama. I. By Professor F. E. Schelling.

VI. The Restoration Drama. II. By Charles Whibley.

VII. The Restoration Drama. III. By A. T. Bartholomew, M.A.

VIII. The Court Poets. By Charles Whibley.

IX. The Prosody of the Seventeenth Century. By Professor George Saintsbury, M.A., F.B.A., LL.D., D.Litt.

X. Memoir and Letter Writers. By Henry B. Wheatley, F.S.A.

I. Evelyn and Pepys.

II. Other Writers of Memoirs and Letters. A.

Other Writers of Memoirs and Letters. B. By A. W. WARD, Litt.D.

XI. Platonists and Latitudinarians. By J. Bass Mullinger, M.A.

XII. Divines of the Church of England, I660-I700. By the Venerable Archdeacon Hutton, B.D.

XIII. Legal Literature. I. By Professor F. J. C. Hearnshaw, M.A., LL.D. II. Selden's Table Talk. By A. W. WARD, Litt.D.

XIV. John Locke. By Professor W. R. SorLEY, Litt.D., F.B.A.

XV. The Progress of Science. By A. E. Shipley, Sc.D., F.R.S.

XVI. The Essay and the Beginning of Modern English Prose. By A. A. Tilley, M.A.

Bibliographies. Table of Principal Dates. Index of Names. 


\section{CAMBRIDGE HISTORY OF ENGLISH LITERATURE \\ VOLUME VIII}

\section{PRESS NOTICES}

Standard. The Master of Peterhouse and his colleague, Mr Waller, are to be congratulated on the steady progress of the Cambridge History of English Literature. The first volume was published in 1907 and now we are confronted with the eighth. They have differed considerably in literary merit, but that is perhaps inevitable when the services of a syndicate of writers have been called into requisition. It is a pleasure to be able to add that the present instalment of a great task is marked by distinction of style and critical discrimination both as regards men and movements in English letters... The whole volume is alive with interest and gives many clues to the interpretation of the wonderful march of thought in almost every direction which rendered memorable the period from the Restoration to the death of William III. The volume is equipped with admirable bibliographies, a table of principal dates, and an exhaustive index. It deserves the welcome which students reserve for a really important contribution to literary criticism.

Daily Telegraph. The eighth volume of this fine work deals with "The Age of Dryden," a period...that to the student is full of deep interest....The new volume of the History is in every way worthy of the earlier oneseach successive instalment the more fully impresses upon us the valuable work which $\mathrm{Dr} \mathrm{A}$. W. Ward and $\mathrm{Mr} \mathrm{A}$. R. Waller are doing. When completed, the Cambridge History of English Literature will be something far more than a work of reference, it will be at once a body of authoritative criticism and exposition for students and a work in which every reader with a true liking for literature will find inexhaustible delight, for the "readability" of the volumes is one of their marked characteristics.

Scotsman. In its eighth volume the Cambridge History of English Literature, a work which has already established its position as the best existing academic text-book of its important subject, goes on its way with conspicuous success, following out in the marshalling of new material the same plan as has proved so effective in preceding volumes. The bibliographies, which form so serviceable a part of this history for readers who wish to attack original texts in the best possible form, have never been better done than in the present volume, the bibliography of Dryden by $\mathrm{Mr} \mathrm{H}$. B. Wheatley being especially noticeable.... The volume is a full and interesting compendium of what modern learning has to teach about the progress of English letters in the forty years that followed the Restoration.

Contemporary Review. The volume of the Cambridge History of English Literature just issued, entitled The Age of Dryden, is one of curious fascination, and has a peculiar value to the student of literature, treating as it does of a period with which students are less familiar than they might be, a period which represents transition rather than decline, a period in which we see the awakening of reality in thought accompanied by the decay of reality in literature. It is these transition periods that are of chief importance to the student of literary evolution. 
A First German Book on the Direct Method. By G. T. Ungoed, M.A., late Exhibitioner of Trinity College, Cambridge, Assistant Master at Acton County School.

Large Crown 8vo. pp. viii +177 (or 136 without vocabulary). Price $2 s .6 d$.

\section{Extract from the Preface}

This book is an attempt to provide an easy course of instruction for pupils who begin the study of German at an early age. It is written entirely in German and contains a series of graduated lessons with questions and exercises, phonetic transcriptions of the first eleven lessons and a brief summary of grammar.

Method. The work is planned for use on the direct and oral method.

Subject Matter. The text has been chosen to teach a vocabulary dealing mainly with the immediate surroundings of the pupils.

Pronunciation. The pronunciation adopted is that prescribed by the stage conference and expounded in the works of Siebs and Viëtor.

Plan of the book. The frame-work of the book is the series of class-room lessons introducing fresh grammatical phenomena, followed, where possible, by a rhyme. and an anecdote.

Nineteenth Century Essays. Edited with an introduction and notes by George Sampson.

Pitt. Press Series. Extra fcap. 8vo. pp. xii +227 . Price $2 s$.

\section{CONTEN'TS}

Carlyle, On History

Macaulay, Ranke's History of the Popes

BAGEHOT, Shakespeare-The Man

Newman, Literature

Ruskin, Sir Joshua and Holbein

ARnold, Marcus Aurelius

Stevenson, A Penny Plain and Twopence Coloured

10 
Catalogue of the Acropolis Musenm. Volume I, Archaic Sculpture. By Gaty Dickins, M.A., Fellow and Lecturer of St John's College, Oxford; sometime Craven Fellow and Student of the British School at Athens.

Crown 8vo. pp. viii +292 . With numerous illustrations. Price Ios. $6 d$. net.

\section{Extract from the Preface}

The first volume of the Acropolis Catalogue deals with the Sculptures of the period preceding the invasion of Xerxes in 480 B.c., at present contained in the first seven rooms of the museum. A number of post-Persian objects in the Entrance Hall are therefore excluded. On the other hand, to avoid subsequent confusion, No. 610 and a few heads in the wall-case in Room $\mathrm{V}$ are included in spite of their later date.

This volume is devoted to sculpture, and therefore the architectural details at present in Room II are omitted as well as objects in terra-cotta. It is hoped that the second volume may contain the rest of the sculpture, the terra-cottas, and the architectural fragments.

The order of the catalogue was at first arranged according to the position of the objects in the museum, but as extensive changes are contemplated there, I have thought it wiser to arrange the catalogue in numerical order, so that any object may be easily found in spite of any future alteration.

\section{CONTENTS}

Introduction

§. Excavations on the Acropolis

§ 2. The Perserschutt

\$. Chronological Study

$\S$ 4. Subjects and Meaning

§ 5. Material and Technique

\$6. The Costume of the female statues

$\S 7$. The Equestrian series

Catalogue of the Acropolis Museum

Index

[ $A$ second volume to be issued later will complete the work] 
Themis. A Study of the Social Origins of Greek Religion. By Jane Ellen Harrison, Hon. LL.D. (Aberdeen), Hon. D.Litt. (Durham), with an Excursus on the Ritual Forms preserved in Greek Tragedy by Professor Gilbert Murray, and a chapter on the Origin of the Olympic Games by $\operatorname{Mr} F$. M. Cornford.

Demy 8vo. pp. xxxii +560 . With 152 illustrations. Price 15 s. net.

\section{Extract from the Introduction}

The title of this book and its relation to my Prolegomena may call for a word of explanation.

In the Prolegomena I was chiefly concerned to show that the religion of Homer was no more primitive than his language. The Olympian gods - that is, the anthropomorphic gods of Homer and Pheidias and the mythographers-seemed to me like a bouquet of cut-flowers whose bloom is brief, because they have been severed from their roots. To find those roots we must burrow deep into a lower stratum of thought, into those chthonic cults which underlay their life and from which sprang all their brilliant blossoming.

When in 1907 a second edition of my book was called for, its theories seemed to me already belated. My sense of the superficiality of Homer's gods had deepened to a conviction that these Olympians were not only non-primitive, but positively in a sense non-religious. If they were not, for religion, starting-points, they were certainly not satisfactory goals. On the other hand, the cultus of Dionysos and Orpheus seemed to me, whatever its errors and licenses, essentially religious. I was therefore compelled reluctantly to face the question, what meaning did I attach to the word religion?

The problem might have continued ineffectively to haunt me, and probably to paralyse my investigations, had not light come rather suddenly from unexpected quarters, from philosophy and social psychology. To France I owe a double debt, indirect but profound, and first and foremost to Professor Henri Bergson...... When I read his L'Évolution Créatrice, I saw how deep was the gulf between Dionysos 


\section{THEMIS-CONTINUED}

the mystery-god and that Olympos he might never really enter. I knew the reason of my own profound discontent. I saw in a word that Dionysos, with every other mystery-god, was an instinctive attempt to express what Professor Bergson calls duree, that life which is one, indivisible and yet ceaselessly changing......My second debt is to Professor Emile Durkheim. In the light of his De la Definition des Phenomènes Religieux and other works I saw why Dionysos, the mystery-god, who is the expression and representation of duree, is, alone among Greek divinities, constantly attended by a thiasos, a matter cardinal for the understanding of his nature. The mystery-god arises out of those instincts, emotions, desires which attend and express life; but these emotions, desires, instincts, in so far as they are religious, are at the outset rather of a group than of individual consciousness... These two ideas, (I) that the mystery-god and the Olympian express respectively, the one durée, life, and the other the action of conscious intelligence which reflects on and analyses life, and (2) that, among primitive peoples, religion reflects collective feeling and collective thinking, underlie my whole argument and were indeed the cause and impulse of my book.

\section{CONTENTS}

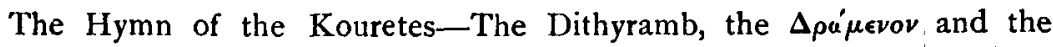
Drama-The Kouretes, the Thunder-Rites and Mana-Magic and TabuMedicine-Bird and Medicine-King-Totemism, Sacrament and SacrificeThe Dithyramb, the Spring Festival and the Hagia Triada SarcophagosThe Origin of the Olympic Games-Daimon and Hero-From Daimon to Olympian-The Olympians-Themis-Index.

Athenaeum. Miss Harrison has written a work which is likely to last long as a monument both of her wide range of classical scholarship and of her sympathetic insight into primitive conditions of mind and society. Ir is a book not only learned but also instinct with a soul. Moreover as every notable creation must be, the book is revolutionary.... Her style of writing is so fresh and free, and she displays such a fine enthusiasm that we are carried along, and feel ourselves not wand-bearers, but Bacchi. The index is magnificent and the letterpress and numerous illustrations are in every way worthy of the Cambridge Press. 
Prehistoric Thessaly. Being some Account of Recent Excavations and Explorations in North-Eastern Greece from Lake Kopais to the Borders of Macedonia. By A. J. B. Wace, M.A., Fellow of Pembroke College, Cambridge, Corresponding Member of the Imperial German Archaeological Institute, and M. S. Thompson, B.A., Craven Fellow in the University of Oxford, Charles Oldham Research Student of Corpus Christi College.

Demy 4to. pp. xvi+272. With a map, 6 coloured plates and I5I figures.

Price $18 s$. net.

\section{Extract from the Preface}

The present work is an attempt to collect in a convenient form all the archaeological evidence as yet available for the prehistoric period in North-Eastern Greece. Chapters I-X, which are purely descriptive, contain full accounts of our own excavations with a summary of the discoveries of others. These we hope will be of permanent value, but how far the theories put forward in the other chapters can be justified time alone can show.

Our own excavations: in North Greece have all been conducted under the aegis of the British School at Athens, of which we are students.

A paper containing an early draft of part of Chapter I was read at a meeting of the Research Committee of the Royal Geographical Society, and has been published in the Geographical Journal, Vol. xxxvir, pp. 63I ff. Of these publications those giving reports of our excavations are superseded by the present work, and the views expressed in the other papers are to be modified in accordance with Chapters XI-XVII and Appendix I.

As regards the transliteration of Ancient Greek we have followed the system recommended by the British School at Athens. According to this all Greek words and names are preserved in the Greek forms and only those that are in common use are Latinised. 


\section{PREHISTORIC THESSACY - CONTINUED}

\section{INTRODUCTION}

\section{CONTENTS}

CHAP.

I. The Greography of North-Eastern Greece, and the Distribution of the Prehistoric Sites

II. The Principal Classes of Pottery and Celts

III. North Thessaly, Rakhmani, Marmariani, Mesiani Maghula, etc.

IV. South-Eastern Thessaly, Sesklo, Dhimini, Pirghos

V. Central Thessaly, Tsangli, Rini

VI. Western Thessaly, Tsani Maghula

VII. Southern Thessaly, Zerelia, Phthiotic Thebes, etc.

VIII. The Spercheus Valley, Lianokladhi

IX. Boeotia and Phocis

$\mathrm{X}$. The Mycenean Period and the Early Iron Age

XI. Architecture

XII. Connections with the South

XIII. Connections with the West

XIV. Connections with the North

XV. Chronology

XVI. The Prehistoric History of North-Eastern Greece

XVII. Ethnological Conclusions

Appendices. Table of Illustrations representing pottery. MuseoGRAPHICAL INDEX. INDEX.

Athenaeum. The explorations and excavations upon which $\mathrm{Mr}$ Wace has been employed for many years, more recently with the assistance of Mir Thompson, here find thorough and accurate publication. The records of discovery upon the various prehistoric sites are fully described and adequately illustrated, so that it is possible to estimate the evidence upon which the conclusions of the explorers are based; and the concluding chapters of the book give a survey of the whole subject as clear as our present state of knowledge will allow, and an excellent and reasonable discussion of the various theories that have been held.... The book is produced by the Cambridge University Press in a suitable form, and is a valuable contribution to our knowledge of a difficult subject.

Scotsman. From the ethnological point of view the conclusions of the book have a not unimportant bearing on the vexed Pelasgian question and the chronological classification of the pottery seems to be a model of sound and careful method. The work is a distinct credit to the younger school of British archaeology, and fully merits the distinction it has received by being issued from the University Press. The printing is excellent and the numerous illustrations are highly successful, the coloured plates being particularly good. There is a first-rate index. 


\title{
The Early English Dissenters in the Light of Recent Research (1550-164I). By Champlin Burrage, Hon. M.A. (Brown University), B.Litt. (Oxon.).
}

Demy 8vo. Cloth. 2 vols. with ro illustrations.

Vol. I, pp. $x x+380$. Vol. II, pp. xvi +354 . Price 20s. net.

\author{
Volume I-HISTORY AND CRITICISM \\ Volume II-Illustrative Documents
}

Contents of Vol. I

An Account of the printed Literature on the Subject (chiefly modern and general) with Criticisms. - Collections of printed Books and Manuscripts that should be visited in the study of early English dissenting history (with notes upon the strong points of each library).-Notes relating to the Contents of the following pages.

The Anabaptists in England before 16r2.-The gradual Growth of Puritanism and its Contribution to the Development of English Separatism until 1581.-Robert Browne and the Organization of the first English Congregational Church.-The Rise of the Barrowists. - The Barrowists under the Leadership of Francis Johnson until I 597.- The Barruwists on the Continent. -Certain obscure Barrowist and Separatist Congregations between $r_{588}$ and I64r. - The Family of Love and the English Seekers.--'The first two English Anabaptist Congregations and their Leaders.-The Congregation of English Anabaptists under the Leadership of Thomas Helwys and John Murton.The English General, or Arminian, Anabaptists between 1624 and r642.The Rise of the Independents. - The History of Henry Jacob's Independent Puritan Congregation in London; and the Story of the Rise of the English Particular, or Calvinistic, Anabaptists.-A Critical Examination of the Gould Manuscript.-The Churches of New England until about I64I.

\section{APPENDices}

An additional Note concerning the book entitled, "Truth's Champion."An additional Note relating to "A very plain and well grounded Treatise concerning Baptisme."-The latest Biscovery relating to John Wilkinson.The Will of Ann Robinson, Mother of John Robinson, Pastor of the Pilgrim Fathers.-Did any English General Anabaptist practise Immersion before I64I?

Times. Mr Burrage's collection of documents is invaluable, including many pieces which have never before been published and forming a remarkably illuminating picture of the earliest English Dissenters.

Athenaeum. We cannot praise too highly the industry of Mr Burrage, and we cordially congratulate him on the result of his arduous labours, which must influence all future histories of English Religion. Nor can we close our review of his volumes without making mention of the modesty with which he puts forth his facts, and the anxiety he always displays to appreciate the efforts of other workers in the same field. The volumes also contain beautifully executed facsimiles of title-pages and documents. 
Foreign Companies and other Corporations. By $E$. Hilton Young, M.A., of the Inner Temple and Oxford Circuit, Barrister-at-Law, City Editor of The Morning Post.

Demy 8vo. Cloth. pp. xii +332 . Price i2s.

\section{Extract from the Preface}

In the year 1904 it fell to my lot to give some consideration to the case of Risdon Iron Works $v$. Furness (p. 185 post). Search for authority about the knotty points involved showed how little consideration had been given to them in this country. These pages, the outcome of that search, are an attempt rather to open up the subject to discussion than to provide a full or final solution.

\section{CONTENTS \\ PART I}

The Juristic Person in Private International Law

Introductory-Status-Capacity-Nationality and Domicile

PART II

Foreign Companies and other Corporations in English Law

General Principles

Status and Capacities-Residence and Domicile-Statutory Regulations-

Service of Process-Liquidation-Revenue-Patents and Trade Marks-

Transfer of Shares-Foreign Sovereigns, States and Governments Appendix

\section{A History of the American Bar. By Charles Warren, of the Boston Bar.}

Demy 8vo. Cloth. pp. xii +586 . Price $16 s$. net.

\section{Extract from the Preface}

This work is not a law book for those who wish to study law, but an historical sketch for those who wish to know something about the men who have composed the American Bar in the past, and about the influences which produced the great American lawyers.

Part I deals with the legal conditions in each of the American Colonies during the 17 th and 18 th centuries, prior to the American Revolution, the status of the Common Law as applied by the courts, the method of appointment of the courts, the leading lawyers, legislation regarding the legal profession, etc.

Part II portrays the growth of the American Bar from the foundation of the Supreme Court to I860. 
Lectures on the Differential Geometry of Curves and Surfaces. By A. R. Forsyth, Sc.D., LL.D., Math.D., F.R.S., sometime Sadlerian Professor of Pure Mathematics in the University of Cambridge.

Large Royal 8vo. pp. xxiv +526. Price 21 s. net.

\section{Extract from the Preface}

The material of the present volume consists of the substance of lectures delivered, from time to time, during my tenure of the Sadlerian professorship of pure mathematics in the University of Cambridge. The last occasion, when such lectures were given by me, was during the Michaelmas Term of 1909 .

As the volume does not pretend to be a complete treatise on differential geometry, and as it is restricted to the contents of my lectures, readers will find that not a few sections of the vast range of the subject are discussed only shortly and that some are left undiscussed. In lectures, my aim was to expound those elements with which eager and enterprising students should become acquainted; they could thus, in my opinion, be best prepared for the penetrating consideration, which is suited for the private study rather than for the lecture-room or the examination-room.

One of my ideals, in lecturing to students, was to provide them with some of the instruments for research; consequently this volume is mainly intended for students who, later, may devote themselves to original work.

A Shorter Geometry. By C. Godfrey, M.V.O., M.A., Head Master of the Royal Naval College, Osborne, and A. W. Siddons, M.A., Assistant Master at Harrow School.

Crown 8vo. pp. xxii +302 . Price 2s. 6 d. Or in four parts :-Part I, Geometry for Beginners, Is. Parts II, III, and IV, Iod. each.

Notes and Answers to Exercises in $A$ Shorter Geometry. By C. Godfrey, M.V.O., M.A., and A.W. Siddons, M.A.

Crown 8vo. pp. iv +16 . Paper covers. Price $6 d$. 
Principia Mathematica. By Alfred North Whitehead, Sc.D., F.R.S., Fellow and late Lecturer of Trinity College, Cambridge, and Bertrand Russell, M.A., F.R.S., Lecturer and late Fellowe of Trinity College, Cambridge. Volume II.

Royal 8vo. pp. xxxiv +772. Price 3os. net.

\section{CONTENTS}

Prefatory Statement of Symbolic Conventions

Part III. Cardinal Arithmetic

A. Definition and Logical Properties of Cardinal Numbers

B. Addition, Multiplication and Exponentiation

C. Finite and Infinite

Part IV. Relation Arithmetic

A. Ordinal Similarity and Relation-Numbers

B. Addition of Relations, and the product of two relations

C. The Principle of First Differences, and the multiplication and exponentiation of relations

D. Arithmetic of Relation-Numbers

Part V. Series

A. General Theory of Series

B. On Sections, Segments, Stretches and Derivatives

C. On Convergence, and the Limits of Functions

An Elementary Treatise on Statics. By S. L. Loney, M.A., Professor of Mathematics at the Royal Holloway College (University of London), sometime Fellowe of Sidney Sussex College, Cambridge.

Demy 8vo. pp. viii +393 . Price 12s.

\section{Extract from the Preface}

The present work is a companion book to my Dynamics of a Particle and of Rigid Bodies. It is meant to cover the usual course of Statics for Students who are reading for a Degree in Science or Engineering, and for Junior Students for Mathematical Honours.

The book starts with the elementary Principles of the subject, but a Student would profit more by its use if he had previously read some elementary work, such as my Elements of Statics. A knowledge of the ordinary processes of the Differential and Integral Calculus is assumed, and also, in some articles, of the notions of Solid Geometry.

It will be evident that, in a book of this size, many parts of the subject must be quite untouched, but I have some hopes that, within the limits I have set to myself, the book is fairly complete. 


\section{CAMBRIDGE MANUALS OF SCIENCE AND LITERATURE}

Editors: P. GiLes, Litt.D., Master of Emmanuel College A. C. Seward, M.A., F.R.S., Professor of Botany in the University of Cambridge

The following volumes, price I $s$. net each in cloth, and $2 s$. $6 d$. net in lambskin, will shortly be added to the series :

The Ballad in Literature. By T. F. Henderson.

The Troubadours. By the Rev. H.J. Chaytor, M.A.

Goethe and the Twentieth Century. By Prof. J.G. Robertson, M.A., Ph.D.

Life in the Medieval University. By R. S. Rait, M.A. $A$ History of Civilization in Palestine. By Prof. R. A.S. Macalister, M.A., F.S.A.

Ancient Assyria. By the Rev. C. H. W. Johns, Litt.D. Methodism. By the Rev. H. B. Workman, D.Lit. Rocks and their Origins. By Prof. G. A.J. Cole. The Origin of Earthquakes. By C. Davison, Sc.D. Spiders. By C. Warburton, M.A.

The following volumes have already been published:

The Coming of Evolution. By Prof. J. W. Judd, C.B., F.R.S.

Heredity in the Light of Recent Research. By L. Doncaster, M.A.

The English Puritans. By the Rev. John Brozen, D.D.

The Idea of God in Early Religions. By Dr F. B. Jevons.

Plant-Animals: a Study in Symbiosis. By Prof. F. W. Keeble, Sc.D.

Cash and Credit. By D.A. Barker, T.C.S.

The Natural History of Coal. By Dr E. A. Newell Arber.

Early Religious Poetry of the Hebrews. By the Rev. E. G. King, D.D.

The History of the English Bible. By the Rev. John Brown, D.D.

Plant-Life on Land. By Prof. $F$. $O$. Bower, Sc.D., F.R.S.

An Historical Account of the Rise and Development of Presbyterianism in
Scotland. By the Rt Hon. the Lord Balfour of Burleigh, K.T., G.C.M.G.

English Dialects from the Eighth Century to the Present Day. By the Rev. Prof. $W . W$. Skeat, Litt.D., D.C.L., F.B.A.

The Administration of Justice in Criminal Matters (in England and Wales). By G. Glover Alexander, M.A., LL.M.

An Introduction to Experimental Psychology. By Dr C. S. Myers.

The Ground Plan of the English Parish Church. By A. Hamilton Thompson, M.A., F.S.A.

The Historical Growth of the English Parish Church. By A. Hamilton Thompson, M.A., F.S.A.

Aerial Locomotion. By E. H. Harper, M.A., and Allan E. Ferguson, B.SC.

Electricity in Locomotion. By $A$. $G$. Whyte, B.Sc. 


\section{CAMBRIDGE MANUALS OF SCIENCE AND LITERATURE}

\section{VOlumes alReady PUblished (CONTINUED)}

New Zealand. By the Hon. Sir Robert Stout, K.C.M.G., LL.D., and J. Logan Stout, LL.B. (N.Z.).

King Arthur in History and Legend. By Prof. W. Lewis jones, M.A.

Early Religious Poetry of Persia. By the Rev. Prof. J. Hope Moulton, D.D., D.Theol. (Berlin).

Greek Tragedy. By \%. T. Sheppard, M.A.

The Wanderings of Peoples. By Dr A. C. Haddon, F.R.S.

Links with the Past in the PlantWorld. By Prof. A. C. Seward, F.R.S.

Primitive Animals. By Geofrey Smith, M.A.
Life in the Sea. By James Johnstone, $B$.Sc.

The Moral Life and Moral Worth. By Prof. Sorley, Litt.D., F.B.A.

The Migration of Birds. By T. A. Coward.

Earthworms and their Allies. By F. E. Beddard, M.A., F.R.S.

Prehistoric Man. By Dr W. L. H. Duckworth.

The Modern Locomotive. By $C$. Edgar Allen, A.M.I.Mcch.E.

The Natural History of Clay. By Alfred B. Searle.

\section{EXTRACTS FROM PRESS NOTICES}

Athenaeum. The five new volumes comprised in this issue maintain the high standard set by their predecessors, and bring the total number published to date up to thirty-two. The volumes on Migration of Birds and Earthworms each contain new material based upon the observations of the authors. Mr Allen's book-the third in the series on Locomotion -is exceptionally well-illustrated, and, while mainly devoted to the actual working of the locomotive, contains an exciting chapter on 'Performance and Speeds.' In the Natural History of Clay Mr Searle has a subject with many aspects, but makes them all interesting. Finally, in Dr Duckworth's book we have a careful study of the relics of our ancestors, giving up-to-date results of the work of the leading investigators.

Spectator. A very valuable series of books which combine in a very happy way a popular presentation of scientific truth along with the accuracy of treatment which in such subjects is essential. High among them for importance of subject and for thoroughness we should rank Prehistoric Man, by W. L. H. Duckworth. The descent of man from the ape is a theory which does not seem to gain ground : many things seem to point to "a greater antiquity of the higher type of human skeleton."...A very interesting volume is The Migration of Birds, by T. A. Coward, with its curious demonstrations of the mechanical side of the subject.

Observer. A series notable alike for quiet scholarship and simplicity of statement.... The format of this library is most tasteful, the volumes are written by experts who know their subjects well enough to exercise easily the art of compression without loss of limpidity, and the price of each book is readily within reach of any book-buyer. 


\title{
CAMBRIDGE GEOGRAPHICAL TEXT-BOOKS
}

\author{
General Editor: G. F. Bosworth, F.R.G.S.
}

Crown 8vo. Bound in Cloth.

Junior: By A. JORDAN, M.Sc. (In preparation)

Intermediate: By A. J. Dicks, B.A., B.Sc. (Now ready)

Senior: By G. F. BosworTH, F.R.G.S. (In preparation)

The Cambridge Geographical Text-books, a series of three volumes planned on the concentric method, are now in course of publication. They will be so graded as to cover the whole course of geographical instruction, and each book will show a proper appreciation of the principles which should form the basis of a good text-book.

The books are to be provided with numerous illustrations and diagrams of various kinds. The maps are of a special character and show features not usually found in the school atlas. There will be no attempt to supply ordinary topographical maps, as it is felt that students should always use a good atlas with the text-books. Photographic illustrations showing important typical scenery will also be freely used, for it is now generally recognised that this feature, though somewhat novel in English text-books, is of considerable and increasing importance.

The books, written by practical teachers, will be found of value in preparation for the various University and Government examinations in general and for Local examinations in particular; and for this purpose each volume will contain a useful selection of exercises and questions based on the text or from those set at various competitive examinations.

Intermediate Volume. By A. J. Dicks, B.A., B.Sc. Crown 8 vo. pp. xii +362 . With 84 illustrations, maps, and diagrams. Price $3 s$.

\section{Extract from the Preface}

This text-book of Geography aims at presenting the main features of the subject in a manner suitable for pupils in the middle forms of secondary schools, the ground covered being approximately that required for the University Junior Local Examinations. 


\section{CAMBRIDGE GEOGRAPHICAL TEXT-BOOKS-CONTINUED}

The earlier chapters deal with Mathematical Geography and the various forms of land and water, so as to provide clata for the elucidation of the chief factors determining climate. The importance of climatic conditions in deciding the flora and fauna of a particular region is recognised throughout the book.

Brief histories of the peoples from the geographical standpoint are included, and their industrial development is associated with the underlying geographical advantages of the country. The results of the recent Census and Trade Returns are introduced, but, as a rule, statistics are sparingly used.

The maps deal with climate and emphasise special features relating to rainfall, winds; etc., which would not be shown in an ordinary topographical atlas. The views illustrate physical features, important industries, and the fauna and flora of certain areas.

\section{Physical Geography for South African Schools.} By Alex. L. du Toit, B.A., F.G.S. Crown 8vo. pp. xii +250 . With 66 illustrations and a Physical
Map of South Africa (folding)." Price 4 s. $6 d$. net.

\section{Extract from the Preface}

This little work has been prepared in order to furnish a concise and somewhat condensed account of the processes of Physical Geography in general and applied to South Africa in particular. Although there are a number of excellent classbooks on this subject, the instances and examples cited in them are to no small extent European and American, and the student in a distant land is not only likely to fail in appreciating at their proper value the illustrations given, but may find some trouble and uncertainty in applying the principles of the science to his own environment.

An attempt has therefore been made in the following pages to meet this natural difficulty and to assist the student in South Africa to a knowledge of the physical geography of the land in which he is residing. 


\section{CAMBRIDGE COUNTY GEOGRAPHIES}

A series of County Geographies, price is. 6d. each, suitable for general use as hand-books to the various counties and also intended for use in schools. Each volume gives an account of the history, antiquities, architecture, natural history, industries, and physical, geological, and general characteristics of the county, and each has two coloured maps (one physical and the other geological) and a large number of photographic illustrations.

The latest additions to the series are:-

Breconshire. By Christopher J. Evans.

West London. By G. F. Bosworth, F.R.G.S. Oxfordshire. By P. H. Ditchfield, M.A., F.S.A.

The following volumes have already been published, viz. :-

Aberdeenshire. By A. Mackie.

Ayrshire. By/. Foster.

Berkshire. By H. W. Monckton.

Buckinghamshire.

By A. Morley Davies.

Cambridgeshire. By Prof. T. McK.

Hughes and Mary C. Hughes.

Carnarvonshire. By J. E. Lloyd.

Cheshire. By T. A. Coward.

Cornzwall. By S. Baring-Gould.

Cumberland. By I. E. Marr.

Derbyshire. By H. H. A. Bemrose.

Devonshire. By $F$. A. Knight and Louie M. Dutton.

Dorset. By A. L. Salmon.

Essex. By G. F. Bosworth.

Fifeshire. By E.S. Valentine.

Gloucestershire. By H.A. Evans.

Hertfordshire. By R. Lydekker.
Huntingdonshire. By W. M. Noble.

Kent. By G. F. Bosworth.

Lanarkshire. By F. Mort.

East London. By G. F. Bosworth.

The Isle of Man. By J. Quine.

Midlothian. By A. Mc Callum.

Monmouthshire. By H. A. Evans.

Norfolk. By W. A. Dutt.

Northamptonshire.

By M. W. Broun.

Nottinghamshire.

By H. H. Swinnerton.

Somerset. By F. A. Knight.

Suffolk. By $W . A$. Dutt.

Surrey. By G. F. Bosworth.

Sussex. By G. F. Bosworth.

Westmorland. By /. E. Marr.

Wiltshire. By A. G. Bradley.

Worcestershire. By L.J. Wills.

Volumes on Dumfriesshire, Perthshire, Renfrezeshire, and North Lancashire will be ready shortly, and volumes on the remaining counties of England, Scotland, and Wales are in an active state of preparation; arrangements for a series of Irish geographies have also been made.

Country Home. The entire series ought to find a place on every country house bookshelf. A motor tour of a county with one of these little volumes as companion will add enormously to its enjoyment and give an idea of the places worthy of note. 
Byways in British Archaeology. By Walter Johnson, F.G.S., Author of Folk-Memory, etc.

Demy 8vo. Cloth. pp. xii +530 . With 99 illustrations. Price Ios. $6 d$. net

\section{Extract from the Preface}

The following chapters, though superficially presenting the appearance of disconnected essays, really possess a strong bond of continuity. Running through the whole, implied, where not actually expressed, will be found an insistence on the principle which, in a former work, I ventured to call folkmemory.

To a large extent the studies are connected with the church and churchyard. The sections which treat of pagan sites, orientation, and burial customs, embody the results of observations relating to some hundreds of buildings in all parts of England and Wales. The chapters on "The FolkLore of the Cardinal Points" and "The Labour'd Ox" partially, at least, break virgin soil. In "The Churchyard Yew" are set down inferences drawn from many years of investigation, the literary side of which has been rendered difficult by the existence, in various modern works, of unfounded statements and hypothetical references. The remainder of the book treats of somewhat more familiar themes, though it is hoped that fresh outlooks are suggested.

Since some of the matters here brought forward have been, and indeed still are, provocative of keen, and even heated controversy, to anticipate agreement with all the conclusions would be sheer folly. Nevertheless, it may be claimed that the facts collected have been carefully sifted, the references conscientiously verified, and the opposing theories honestly presented.

\section{CONTENTS}

Churches on Pagan Sites-The Secular Uses of the Church Fabric-The Orientation of Churches-The Orientation of Graves-Survivals in Burial Customs-The Folk-Lore of the Cardinal Points-The Churchyard YewThe Cult of the Horse- "The Labour'd Ox."

Athenaeum. In these 500 pages $\mathrm{Mr}$ Johnson has brought together a series of essays on archaeological subjects, each of which shows considerable reading and accurate research.... The amount of information compactly presented is remarkable, and it may fairly be said that every reasoning British archaeologist ought to read these pages....Throughout the volume is well illustrated. 
The Heroic Age. By H. Munro Chadwick, Fellow of Clare College, Cambridge.

Cambridge Archaeological and Ethnological Series. Demy 8vo. Cloth. pp. xii + 474. With 3 maps. Price I2s, net.

\section{Extract from the Preface}

The type of poetry commonly known as heroic is one which makes its appearance in various nations and in various periods of history. No one can fail to observe that certain similar features are to be found in poems of this type which are widely separated from one another both in date and place of origin. In view of this fact it has seemed worth while to attempt a comparative study of two groups of such poems with the object of determining the nature of the resemblances between them and the causes to which they are due.

The first part of the book deals with the early heroic poetry and traditions of the Teutonic peoples, more especially with those stories which were the common property of various Teutonic peoples.... The subjects discussed include the distribution of the stories and the relationship between the various versions of them, the antiquity of the earliest poems and the conditions under which they were produced. Lastly, an attempt has been made to estimate the significance of the various elements, historical, mythical and fictitious, of which the stories are composed.

The second part deals with Greek heroic poetry and traditions. These relate to a period for which little or no external evidence is available ; and consequently they present many problems, the bearings of which can hardly be estimated without reference to the existence of similar phenomena elsewhere. In general I have followed the same plan as in the first part, and made use throughout of the results obtained there.

In the third part attention has been called to the existence of a number of somewhat striking characteristics common to the two groups of poems and an attempt made to account for them. The conclusion to which I have been brought is that the resemblances in the poems are due primarily to resemblances in the ages to which they relate and to which they ultimately owe their origin. 
The English Provincial Printers, Stationers and Bookbinders to I557, The Sandars Lectures, I9II. By E. Gordon Duff, M.A. Oxon., sometime Sandars Reader in Bibliography in the University of Cambridge.

Crown 8 vo. pp. $x+153$. With 4 plates. Price $4 s$. net.

\section{Extract from the Preface}

The work of the provincial printers, stationers and bookbinders forms a subject of the greatest interest, and one which has hitherto hardly received adequate attention.

The presses of the two University towns, Oxford and Cambridge, have been very fully treated, and, in a lesser degree, those of St Albans and York, but with these exceptions the remaining towns have been curiously neglected, and our knowledge concerning such important printing centres as Ipswich, Worcester and Canterbury seems to have advanced but little since Herbert issued the third volume of his Typographical Antiquities over a hundred and twenty years ago.

There is still much to be learned about these provincial presses. The careers of the printers, their types, their woodcuts, their ornaments have still to be traced and a number of books which have disappeared within recent years remain to be re-discovered.

I. Oxford

\section{CONTENTS}

II. St Albans, York and Hereford

III. Oxford Second Press and Cambridge

IV. Tavistock, Abingdon, St Albans Second Press, Ipswich, Worcester, Canterbury, Exeter, "Winchester" and "Greenwich"

Appendix I. List of books printed by provincial printers or for provincial stationers

Appendix II. List of Authorities

Athenaeum. An excellent little book, written with an authority and a knowledge of early English printed books which no one else of the present day possesses, and is devoted to a subject which has hitherto, to use the author's words, hardly received adequate attention. It is composed of the four Sandars Lectures for IgI I in the University of Cambridge, together with Appendixes giving a list of books printed by or for provincial printers and stationers, and a useful Bibliography of the subject....Those who know Mr Duff's work will require no commendation on our part to send them to his pages, and by this time the number must include every one interested in the history of English book production. 
The Scottish Liturgy for the Celebration of the Holy Eucharist and Administration of Holy Communion, commonly called the Scottish Communion Office.

Pica 8vo edn. pp. 34. Buckram, is. 6 d. net.

Bourgeois 32mo edn. pp. 32. Paper covers, Id. net; cloth cut flush, $4 d$. net.

The Scottish Liturgy for the Celebration of the Holy Eucharist and Administration of Holy Communion, commonly called the Scottish Communion Office, together with the Collects, Epistles and Gospels from the Book of Common Prayer and the additional Collects, Epistles and Gospels sanctioned in the Scottish Church.

Altar-book edn, Great Primer, Super Royal 8vo. pp. 198. Buckram, 5s. net.

Altar-book edn, with English Communion Office added. pp. $198+32$. Persian Morocco, $21 s$. net.

Bourgeois 32mo edn. pp. 234. French Morocco, 3s. net; Persian Morocco, 4 s. net.

Permissible Additions to and Deviations from the Service Books of the Scottish Church as Canonically Sanctioned.

Pica 8vo edn. pp. 64. Buckram, is. 6a. net.

Bourgeois $32 \mathrm{mo}$ edn. pp. 56. Paper covers, $1 d$. net; cloth cut flush, $4 d$. net.

The Scottish Liturgy for the Celebration of the Holy Eucharist and Administration of Holy Communion, commonly called the Scottish Communion Office, together with Permissible Additions to and Deviations from the Service Books of the Scottish Church as Canonically Sanctioned.

Pica 8vo edn. pp. $34+64$. Buckram, 2s. 6d. net; Persian Morocco, 7s. 6d. net.

Bourgeois 32 mo edn. pp. $32+56$. Paper covers, $2 d$. net ; cloth cut flush, $6 d$. net ; French Morocco, $2 s$. net ; Persian Morocco, $3^{s}$. net

The Syndics of the Press have recently published, for the Publication Committee of the Episcopal Church in Scotland, the Scottish Communion Office and the Permissible Additions to and Deviations from the Service Books of the Church as approved by the College of Bishops.

The history of the Scottish Communion Office is briefly this. After the failure of the attempt to introduce the use of the 1637 Prayer-book in Scotland, for many years no form of liturgy was in any general use in that kingdom. After the Revolution of 1688 the desire for a liturgy grew and in Queen Anne's time considerable numbers of English Prayer-books 


\section{THE SCOTTISH LITURGY-CONTINUED}

were brought into Scotland. But the national sentiment of the north, where Episcopacy was strong, resulted in the revival and separate printing of the Communion Service from the Prayer-book of 1637 . Little by little modifications were made in the 1637 Communion Service with a view to bringing it more into conformity with the Liturgies of the early Church. The first of the separate reprints of the Service is undated, the second is dated 1722 .

In 744 there was published The Ancient Liturgy of the Church of Jerusalem, an edition by Dr Rattray, Bishop of Dunkeld, of the Liturgy of St James. Owing mainly to the influence of this book, Bishop Falconer and Bishop Forbes issued in 1764 a new edition of the Communion Service. The 1764 Liturgy became the service book of all the native Scottish Episcopal congregations. It was the rite used when the first American Bishop, Samuel Seabury, was consecrated at Aberdeen in 1784; one result of this Scottish origin of the Anglican-American Episcopate being that the American Liturgy is derived from the Scottish form rather than from the English. During the first half of the nineteenth century edition after edition of the Scottish Communion Office was printed at Aberdeen. One or two attempts at revision were made but without success until, by the recent action of the Provincial Synod, some slight revision has been effected, which sets up an authoritative standard for all editions.

Of the variations from the Prayer-book contained in the Permissible Additions to and Deviations from the Service Books of the Scottish Church a certain number have long been traditional in Scotland, although with few exceptions they have not hitherto received definite canonical sanction. The new matter includes additional Collects, Epistles and Gospels for occasions such as Harvest Thanksgiving, Dedication Festival, Marriage, and the festivals of certain Scottish saints, a wider choice of Scripture lessons, modifications of the burial service, a form for the burial of children, and a number of prayers for special occasions.

The Cambridge University Press have in preparation a complete Prayer-book for Scottish use, embodying in proper order in its text the Scottish Communion Office and all the new matter now sanctioned. 


\section{FURTHER PUBLICATIONS}

The Odes and Psalms of Solomon. The Syriac Text. By.J. Rendel. Harris, M.A. Royal 8vo. 5s. net.

Mar Shimin, Catholicos of the East. A Poem which obtained the Seatonian Prize in the University of Cambridge in igı I. By Frederick George Cole, M.A., St John's College, Vicar of Bilton-in-Holderness. Demy 8vo. Is. net.

The Forty Martyrs of the Sinai Desert and The Story of Eulogios. From a Palestinian Syriac and Arabic Palimpsest. Transcribed by Agnes Smith Lewis, M.R.A.S.; Hon. D.D. (Heidelberg); Litt.D. (Dublin); LL.D. (St Andrews); Ph.D. (Halle-Wittenberg). Horae Semiticae, No. IX. Crown 4to. With facsimile and 2 illustrations. 7s. 6d. net.

The Revised English Grammar. $A$ new edition of The Elements of English Grammar based upon the recommendations of the Committee on Grammatical Terminology. By Alfred S. West, M.A. Fcap. 8vo. 2s. $6 d$.

The Revised English Grammar for Beginners. $A$ new edition of An English Grammar for Beginners based upon the recommendations of the Committee on Grammatical Terminology. By Alfred S. West, M.A. Fiap. 8vo. Is.

Gotthold Ephraim Lessing: Nathan der Weise, Ein Dramatisches Gedicht. Edited by J. G. Robertson, Professor of German in the University of London. Pitt Press Series. Extra fcap. 8vo. Price 3s. 6d. (Not 3s. 6d. net as stated in Bulletin No. XXV, January 1912.)

The Study of Timber and Forest Products in America. A report presented to the Forestry Committee of the University of Cambridge on a visit to the United States and Canada for the purpose of studying the Research. Work and Educational Methods of the Forestry Department and Forestry Schools in those countries. Crown 8vo. 6d. net. 
A Descriptive Catalogue of the MSS. in the Library of Corpus Christi College, Part VI, Nos. 451-538. By Montague Rhodes James, Litt.D., F.B.A., Provost of King's College, Cambridge, Royal 8vo. 7s. 6d. net.

Biographical History of Gonville and Caius College. Vol. IV. In continuation of Volumes I-III, compiled by John Venn, Sc.D., F.R.S., Senior Fellow and President. Part 1. Admissions since January 1, 1899, edited by E. S. Roberts, M.A., Master. Part II. Chronicle of the College Estates, compiled by E. J. Gross, M.A., Senior Fellow and formerly Bursar. Royal 8vo. 20s. net.

The Works of John Caius, M.D., Second Founder of Gonville and Caius College and Master of the College 1559-1573. With a Memoir of his Life by John Venn, Sc.D., Senior Fellow and President of the College. Edited by E.S. Roberts, Master. I 8 s. net.

Biometrika. A Journal for the statistical study of biological problems. Edited by Karl Pearson. Vol. VIII, Parts 3 and 4 (together). Imperial 8vo. 20s. net.

The British Journal of Psychology. Edited by W. H. R. Rivers and C. S. Myers. Royal 8vo. Vol. IV, Parts 3 and 4 (together). Ios. net. Vol. $V$, Part I. 4s. net.

The Journal of Agricultural Science. Edited by Professor R. H. Biffen, M.A., A. D. Hall, M.A., F.R.S., and Professor T. B. Wood, M.A. Vol. IV, Part 3. Royal 8vo. 5s. net.

The Journal of Genetics. Edited by W. Bateson, M.A., F.R.S. and R. C. Punnet, M.A. Vol. I, No. 4 and Vol. II, No. I. Royal 8vo. ios. net eaih.

The Journal of Hygiene. Edited by G. H. F. Nuttall, M.D., F.R.S. Royal 8vo. Vol. XI, No. 4. 7s. net. Plague Supplement I, being the sixth report on Plague investigations in India. 7 s. net.

The Journal of Physiology. Edited by J. N. Langley, Sc.D., F.R.S. Royal 8vo. Vol. XLIII, No.6. 6s. 6d. net. Vol. XLIV, Nos. I and 2. 7s. 6d. net. 
The Modern Language Review. Edited by $J$. $G$. Robertson, G. C. Macaulay, and H. Oelsner. Vol. VII, Nos. I and 2. 4s. net.

Parasitology. Edited by G. H. F. Nuttall, F.R.S. and A. E. Shipley, F.R.S. Royal 8vo. Vol. IV, No. 4 , 7s. net and Vol. V, No. I, IOs. net.

\section{Alterations in Price}

English Composition. By W. Murison. Crown 8vo. Price 4s. 6d. Also re-issued in two parts:

Part I. Use of Words, Figures of Speech, Sentence and Paragraph Construction, Punctuation. Price 2s.6d.

Part II. Essay, Paraphrase, Précis, Style, Prosody, Kinds of Literature. Price 2s. $6 d$.

A Grammar of the German Language. By G. H. Clarke and C. J. Murray. Crown 8vo. Price 5 s.

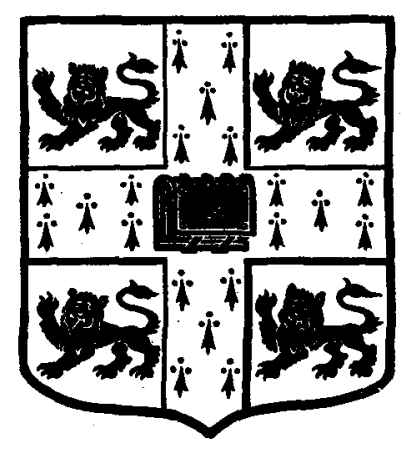

The Cambridge University Press Bulletin is published early in each term and will be posted free of charge to any address sent to the Cambridge University Press, Fetter Lane, London, E.C., where books mentioned in the Bulletin, or earlier publications of the Press, may be inspected.

Cambridge: Printed at the University Press. 


\title{
OBSERVATIONS UPON THE NATURAL HISTORY OF EPIDEMIC DIARRHOEA
}

\author{
By O. H. PETERS, M.D., D.P.H.
}

Royal 8vo. Price 7s, net

This treatise, here reprinted from the Journal of Hygiene (Vol. X), embodies both the practical observations made at Mansfield, and also the results of previous theoretical inquiry into the phenomena of the epidemic curve, representing three years of close research.

"Dr Peters has done his work in a thoroughly scientific manner.... It is a valuable addition to the literature of a subject which yearly demands a toll of many thousand lives."-Athenaeum

"Dr Peters gives an exhaustive account of the conditions relating to the disease, and examines the various theories as to its causation and spread.... This monograph is a thoughtful and valuable contribution to the literature of a devastating disease, and deserves careful consideration by all who are concerned in its study."-Lancet

"Deserves and will receive close study from all interested in this important problem of public health."-British Medical Journal

"The book bears obvious evidence of the thoroughness and intensity of effort with which the statisties were collected, and the minute records as well as the very elaborate analyses which accompany them deserve careful consideration and study, and are a valuable contribution to our knowledge of the aetiology of epidemic diarrhoea."-Medical Officer

\section{PARASITOLOGY}

Edited by GEORGE H. F. NUTTALL, F.R.S., Quick Professor of Biology in the University of Cambridge, and A. E. SHIPLEY, F.R.S., Reader in Zoology, Cambridge, assisted by EDWARD HINDLE, Рн.D.

PARASITOLOGY is published about four times a year. The numbers are afterwards issued in volumes each containing four numbers and amounting to between 400 and 500 pages, with plates and figures.

Volumes I, II, III and IV (1908-11) are now ready. In four parts, paper covers, 21s, net per volume. Bound in buckram, 25s. net per volume.

In view of the desirability of keeping the standard of the artieles and illustrations published in Parasitology at its present level, the publishers have decided that it is necessary to raise the subseription price from $£ 1.18 .0 d$. to $£ 1.10$ s. $0 d$. per volume, post free, from the first number of Volume V. The price of the single parts will, in future, be 108 . each.

Subscribers to the Journal of Hygiene may obtain single numbers of Parasitology at the reduced price of $7 \varepsilon, 6 d$. net, or may become subscribers at the reduced rate of $£ 1.18 .0 d$. per volume.

The publishers believe that they will retain the support of all present subscribers to the Journal in their endeavours to maintain it under similar conditions as to its contents to those which have prevailed in the case of Volnmes I-IV.

Subseriptions may be sent to any Bookseller, or to Mr C. F. Char, Manager, Cambridge University Press, Fetter Lane, E.C. A Prospectus will be sent on application. 


\section{CONTENTS}

\section{(All rights reserved)}

Newman, L. F., Robinson, G. W., Halnan, E. T. and Neville, H. A. D. Some Experiments on the Relative Digestibility of White and Wholemeal Breads . . . . .

Harden, Arthur and Lane-Claypon, Janet E. Occurrence of Ferments in the Sterile Milk collected by Milking Tube from Cows and Goats . . . . . . .

Ledingham, J. C. G. and Dean, H. R. The Action of the Complement-Fractions on a Tropin-B. Typhosus System with Comparative Haemolytic Experiments. . . . .

Penfold, W. J. On the Specificity of Bacterial Mutation, with a Résumé of the Results of an Examination of Bacteria found in Eaeces and Urine, which undergo Mutation when grown on Lactose Media. (With Plates I to IV) . .

Tebbutr, Hamiton. On the Bacteriology of Asylum Dysentery

Glynn, Ernest E. and Lewis, F. C. The Detection of Anthrax Spores in Industrial Material . . . . .

The Journal of Hygiene is issued as material accumulates. A volume containing about 500 pages, with plates and figures, is issued annually.

Volumes I, II, and III (1901-3) complete. In Four Parts, paper covers, 15s. net per volume. Bound in buckram, 18s. 6d. net per volume.

Volumes IV, V, VI, VII, VIII, IX, X and XI (1904-11) complete. In Parts, paper covers, 21s. net per volume. Bound in buckram, 25s. net per volume.

Papers for publication may be sent to Prof. Geo. H. F. Nutrall, F.R.S., 3 Cranmer Road, Cambridge, or to the associate Editors. Other communications should be addressed to the University Press, Cambridge.

Papers forwarded to the Editors for publication are understood to be offered to the Journal of Hygiene alone, unless the contrary is stated.

Contributors receive seventy-five copies of their papers free. Additional copies may be had at cost price: these should be ordered when the final proof is returned.

The subscription price is $£ 1.18$. per volume (post-free), payable in advance; single numbers 78 . net. Subscriptions may be sent to any Bookseller, or to Mr C. F. CLAY, Manager, Cambridge University Press, Fetter Lane, London, E.C.

Plague Numbers, Vol. VI. no. 4 (not sold separately), Vol. VII. nos. 3 and 6, and Vol. VIII. no. 2, Vol. X. no. 3, Price 6s. net each. Bound volumes containing all five numbers, with Index, are also issued, price 20s. net.

A new series of Plague Supplements is now being issued; the first of these, which is now ready, contains the Sixth Report on Plague Investigations in India. They will be, in pagination, completely independent of the Journal although subscribers to the latter will receive copies without extra cost. Price to nonsubscribers 7s. net. 